\title{
Experimental Study of Biogas Production from Cow Dung as an Alternative for Fossil Fuels
}

\author{
Moutaz Benali*, Tarek Hamad, Yousif Hamad \\ Department of Sustainable and Renewable Energy Engineering, Omar Al-Mukhtar University, El-Beida, Libya \\ Email: *moutaz.benali@omu.edu.ly
}

How to cite this paper: Benali, M., Hamad, T. and Hamad, Y. (2019) Experimental Study of Biogas Production from Cow Dung as an Alternative for Fossil Fuels. Journal of Sustainable Bioenergy Systems, 9, 91-97.

https://doi.org/10.4236/jsbs.2019.93007

Received: May 17, 2019

Accepted: August 4, 2019

Published: August 7, 2019

Copyright $\odot 2019$ by author(s) and Scientific Research Publishing Inc. This work is licensed under the Creative Commons Attribution International License (CC BY 4.0).

http://creativecommons.org/licenses/by/4.0/

\begin{abstract}
To treat the problem of fossil fuel usage and greenhouse gas emissions, biogas is considered a potential source of clean renewable energy. The aim of the work is to analyze the amount of biogas and ph from cow dung when an anaerobic digester operates in the mesophilic mode. In this study is presented the experimental investigation of biogas production from cow dung as an alternative energy resource. This is work using an 18 Liters capacity plastic as prototype biogas plant, plant to inspect the anaerobic digestion in producing biogas. The digester was batch operated and daily gas produced from the plant was observed for 30 days. The digester was fed within the ratio of 1:1 of dung to water respectively. The operating temperatures of the digester were maintained within mesophilic conditions. The Biogas production from cow dung fluctuates from the first day to the thirtieth day between 0 and $340 \mathrm{ml}$. $\mathrm{The} \mathrm{pH}$ of cow dung is gradual reduction within the retention period.
\end{abstract}

\section{Keywords}

Biogas Production, Cow Dung, Anaerobic Digestion, Mesophilic, Clean Energy

\section{Introduction}

Due to the population growth and the industrial development, world energy consumption considerably increases in the last decades. The use of fossil fuels is still the main energy sources. However, fossil fuels are not renewable energies, further, they are highly polluting, and their production tends to decrease during the next few decades [1]. Yet, the increased energy consumption based on fossil fuels affects our environment through the greater amounts of greenhouse gas emissions, the environmental pollution of water, air and soil, and the climate changes, which dramatically influence the quality of life and the health of people. 
Therefore, it is important to develop new sustainable energy supply systems that cover the increasing energy demand from renewable sources. Reducing greenhouse gas emissions through renewable energy production is of rising importance [2].

Biogas, produced by anaerobic digestion of wastewater, organic waste, agricultural waste, industrial waste, and animal by-products is a potential source of renewable energy [3].

Anaerobic digestion is a series of biological process in which microorganism breaks down biodegradable material in the absence of oxygen. It is a step by step process where the organic carbon is mainly converted to carbon dioxide and methane. Figure 1 shows the process of producing biogas divided into hydrolysis, acidogenesis, acetogenesis and methanogenesis [4].

Biogas is mainly methane and carbon dioxide and small amounts of hydrogen sulfide. The gases methane, hydrogen, and carbon monoxide can be combusted or oxidized with oxygen. This energy release allows biogas to be used as a fuel [5]. It can also be used in a gas engine to convert the energy in the gas into electricity and heat and even for internal combustion engines. Biogas can be compressed, the same way natural gas is compressed. When it becomes bio-methane, biogas can be upgraded to natural gas standards [6].

The rate of biogas production depends greatly on the temperature for digesters. Anaerobic digestion process generally occurs at three temperature ranges. These ranges are defined as psychrophilic $\left(15^{\circ} \mathrm{C}-20^{\circ} \mathrm{C}\right)$, mesophilic $\left(30^{\circ} \mathrm{C}-\right.$ $\left.40^{\circ} \mathrm{C}\right)$ and thermophilic $\left(50^{\circ} \mathrm{C}-60^{\circ} \mathrm{C}\right)$.

During biological decomposition and conversion processes, the rate of chemical
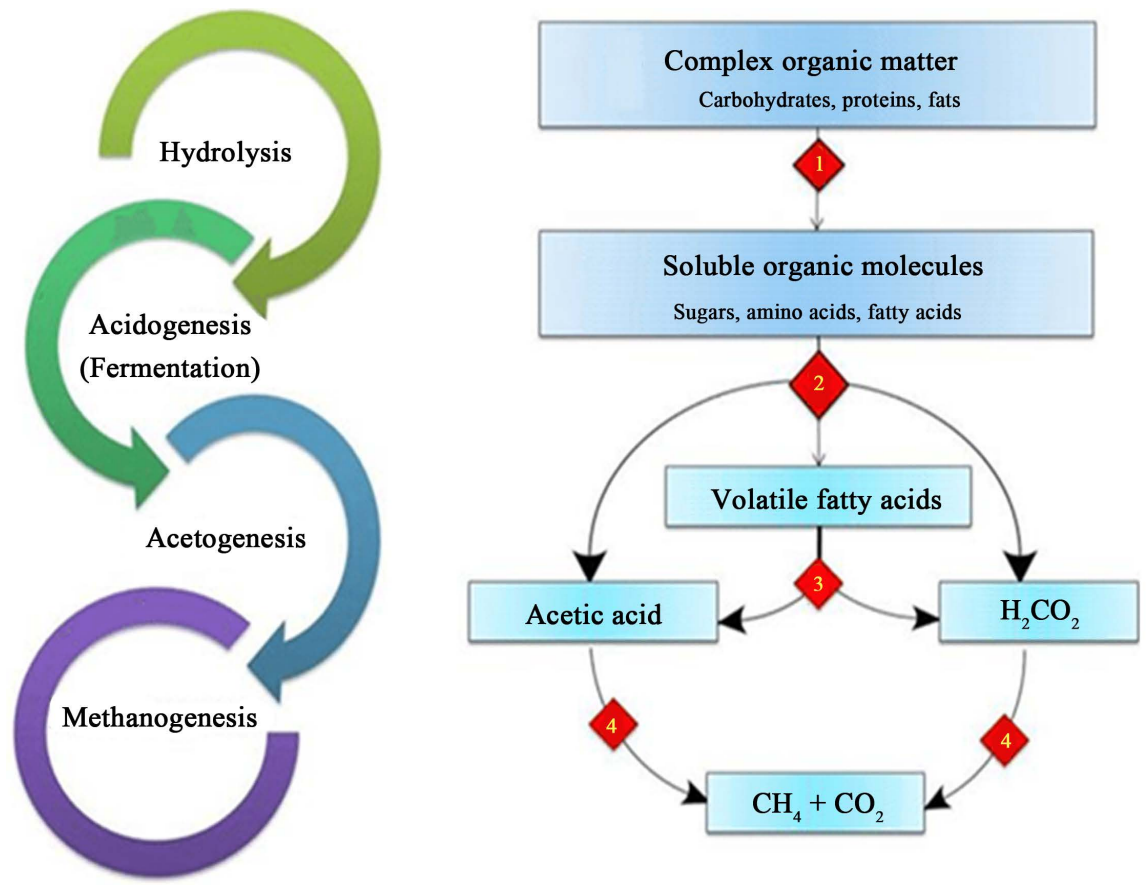

Figure 1. Flow chart of anaerobic digestion process. 
reaction increases with the increase in the surrounding temperature. However, there should not be rapid temperature fluctuations during the digestion process, due to that methanogenic bacteria are sensitive to temperature conditions. A sudden change in temperature will hamper the methanogenic bacteria resulting in decreased biogas production. The optimum temperature for anaerobic digestion and methanogenic bacteria is found to be between $30^{\circ} \mathrm{C}$ to $40^{\circ} \mathrm{C}$ [7]. The relative growth rate of methanogens under different temperature conditions is presented in Figure 2.

\section{Aim of the Study}

The main objective of this research is investigation of biogas production by decomposition cow dung is needed for the students' level. It is also trusted worth saying that the cow dung is generally available in the Arab counties.

\section{Components of the Experiment}

1) Two plastic tanks $18 \mathrm{~L}$. The first tanks for digester and another tank for fill water.

2) Graduated cylinder $2000 \mathrm{~mL}$ for measure volume biogas produce.

3) Connections.

4) Rubber tube.

\section{Experimental Set-Up}

This research was made to a simple demonstration of biogas production by decomposition of cow dung. The digester made of plastic tank of 18 liters capacity was used for set-up. The experimental the set-up is shown in Figure 3. The full setup for this experimental was the connection of the digester to the water displacement setup for the gas collection. The water displacement method of gas collection is a method in which gas is allowed to replace water at equal volume of water displaced and this was used to determine the volume of gas produced daily. The mode of feeding used was a batch feeding (discontinued feeding). This

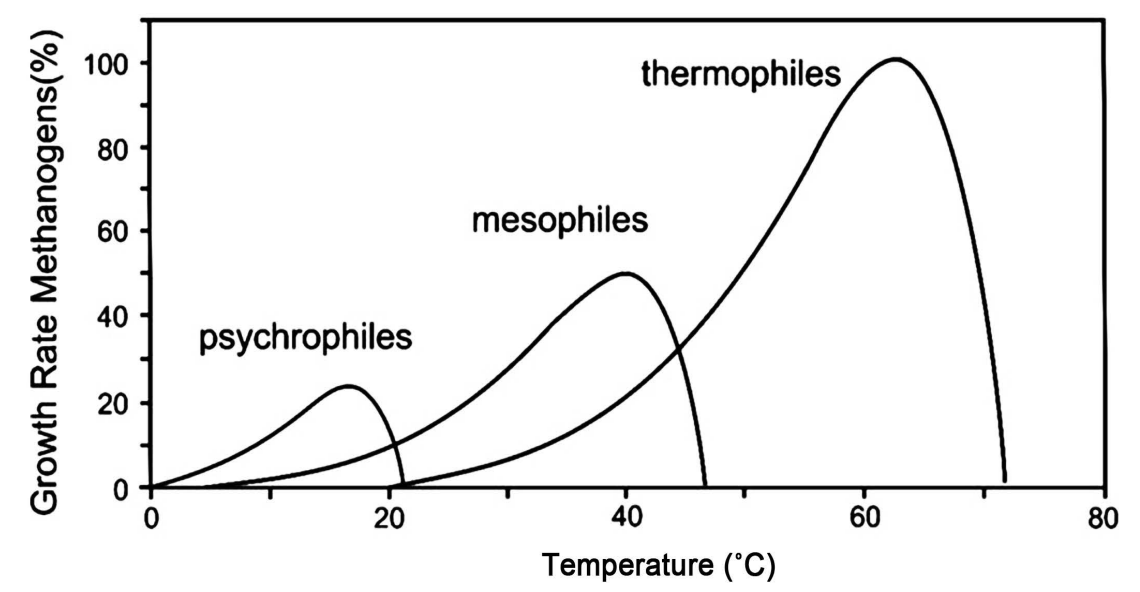

Figure 2. Relation between temperature and growth rate of methanogens. 


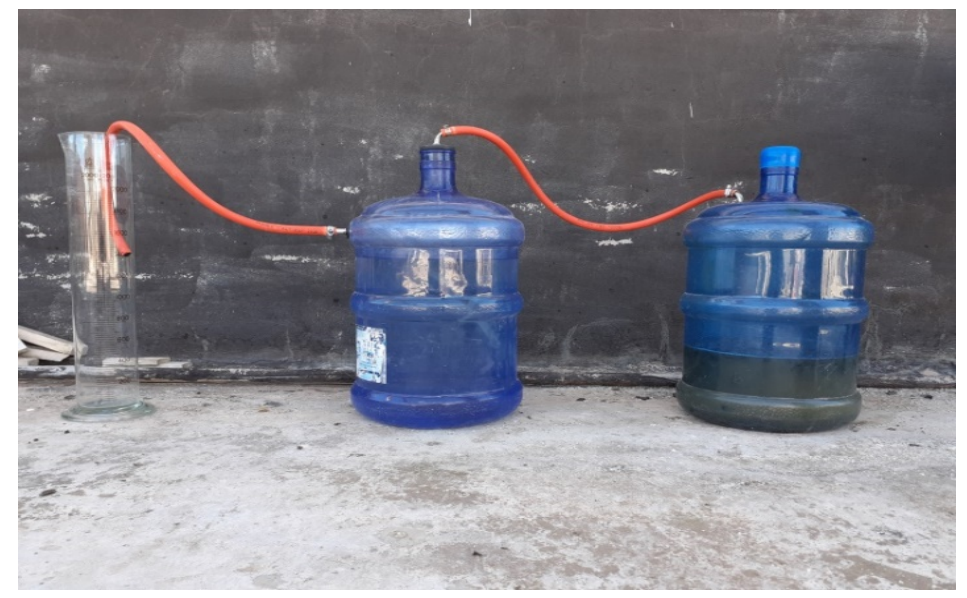

Figure 3. The experimental setup.

simply means loading the digester at once and maintaining a closed environment throughout the retention period. The procedures taken during feeding of the digester are as follow:

1) $5 \mathrm{~kg}$ of the cow dung was weighed and 5 liters of water was mixed thoroughly with of the waste in the ratio of $1: 1$.

2) The mixture of the waste was poured into digester.

The digesters were operated at temperature in the mesophilic range with a hydraulic retention time of 30 days.

\section{Measurement Methods}

Biogas production from the digesters was measured daily by graduated cylinder. Measure $\mathrm{pH}$ was analytical and food laboratory at Omar Al-Mukhtar University by using $\mathrm{pH}$ meter.

\section{Results and Discussion}

This experiment was carried out using cow dung. The details of the experiment are illustrated in Table 1.

Figure 4 shows the volume biogas produced from cow dung within the retention period 30 days. For biogas produced in cow dung, biogas was not produced for the first 8 days since it takes more time for cow dung to decompose afterward which gas is being produced. This is forecast because non growth of methanogenic bacteria. This can also be traced to the fact that most cows feed on fibrous materials and microorganisms require a longer time to degrade fibrous materials. Production of gas from cow dung started on day 9 of the retention period by producing average biogas of $30 \mathrm{ml}$, thereafter increases to $100 \mathrm{ml}$ on day 10 and reduces to $50 \mathrm{ml}$ on day 12. At day 13, the biogas produced was $160 \mathrm{ml}$ in which decreases back to $45 \mathrm{ml}$ on the next day and increases thereafter until it reached the peak on day 22 with $340 \mathrm{ml}$ biogas production after which it begins to reduce till the completion of the retention period.

Figure 5 illustrates the $\mathrm{pH}$ of cow dung within the 30 days retention period. 


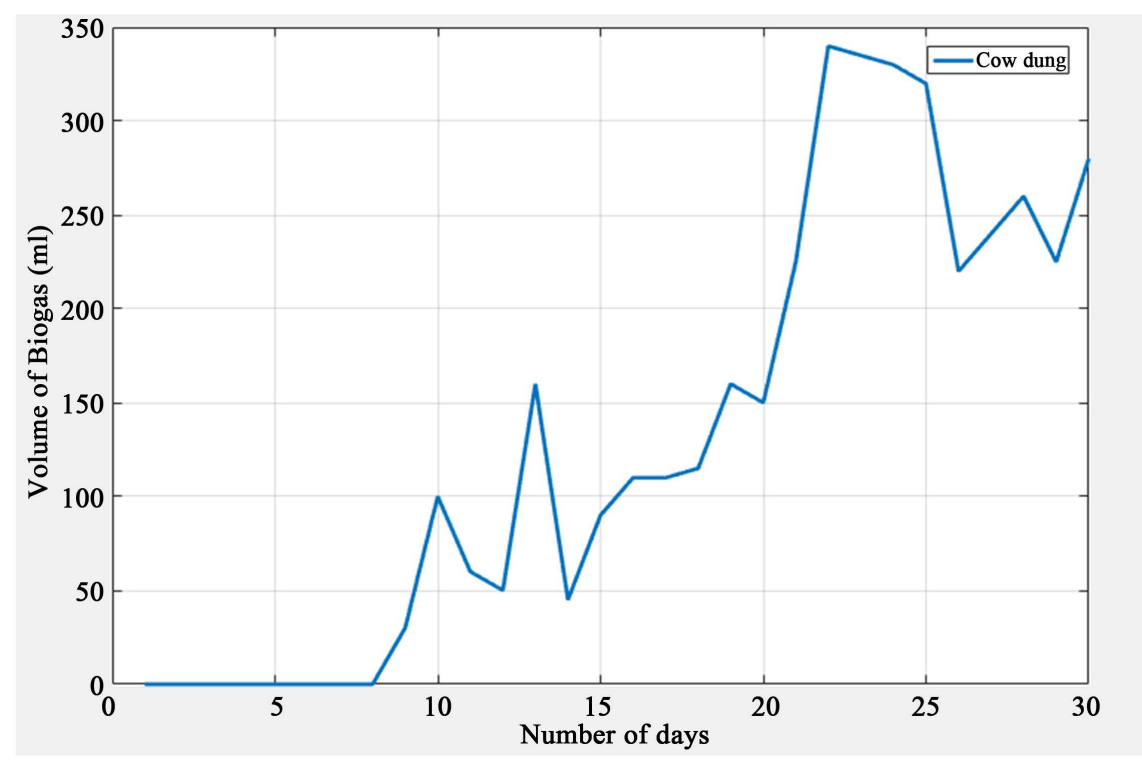

Figure 4. Volume of biogas against number of days.

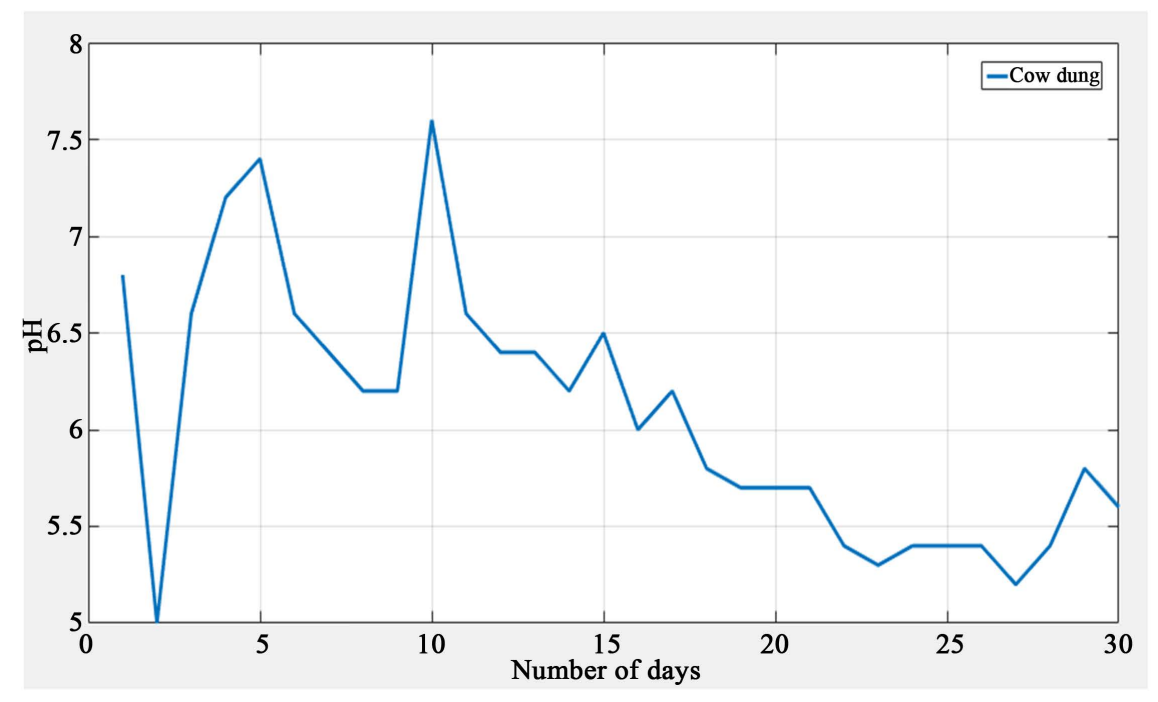

Figure 5. pH of Slurry against number of days.

Table 1. The details of the experiment.

\begin{tabular}{cc}
\hline Mass of cow dung & $5 \mathrm{Kg}$ \\
\hline Mass of water & 5 liters \\
total solid (TS) & $18.7 \%$ \\
temperature & $30-35^{\circ} \mathrm{C}$ \\
hydraulic retention time & $(30)$ days \\
\hline
\end{tabular}

The $\mathrm{pH}$ for cow dung fluctuate from the first day to the tenth day between 5 and 7.4, after which begins to decrease gradually for the remaining days of the retention period. As it was observed in the first few days, the $\mathrm{pH}$ of cow dung decreases due to high volatile fatty acid. The gradual reduction explains the 
gradually change of stage of the production of biogas, from hydrolysis to acidogenesis in which the slurry become acidic and form substrate after which it produces biogas.

\section{Conclusion}

This research shows that biogas can be produced from cow dung through anaerobic digestion. This dung is continuously offered in our location and can be used as an alternative energy resource. The research exposed further that cow dung as animal waste has large possibilities for production of biogas. The application should be encouraged due to high volume of biogas produces.

\section{Recommendations}

In the future, an experiment would be expanded for including all types of animal waste.

\section{Acknowledgements}

The researches would like to thank the Department of Sustainable and Renewable Energy Engineering, Omar Al-Mukhtar University, El-Beida Libya for their financial support.

\section{Conflicts of Interest}

The authors declare no conflicts of interest regarding the publication of this paper.

\section{References}

[1] Gazali, T. and Moqsud, M. (2017) The Effectiveness of Animal Dungs and Leaf Mold for Bioelectricity Generation Using Microbial Fuel Cell with Soils. Journal of Sustainable Bioenergy Systems, 7, 165-181. https://doi.org/10.4236/jsbs.2017.74012

[2] Femi, T., Ahmed, I., Helen, O. and Satyavolu, J. (2018) Production of Ethanol from Cassava Peelings Using a Developed Percolation Reactor. Journal of Sustainable Bioenergy Systems, 8, 107-115. https://doi.org/10.4236/jsbs.2018.84008

[3] Situmbeko, S. (2017) Decentralised Energy Systems and Associated Policy Mechanisms-A Review of Africa. Journal of Sustainable Bioenergy Systems, 7, 98-116. https://doi.org/10.4236/jsbs.2017.73008

[4] Benali, M., Hamad, T., Hamad, Y. and Belkhair, A. (2019) The Hydrogen Energy Potential of Solid Waste: A Case Study of Misrata City. Advances in Biological Chemistry, 9, 45-53. https://doi.org/10.4236/abc.2019.92004

[5] Al Mamun, M.R., Tasnim, A., Bashar, S. and Uddin, M.J. (2018) Potentiality of Biomethane Production from Slaughtered Rumen Digesta for Reduction of Environmental Pollution. AIMS Energy, 6, 658-672. https://doi.org/10.3934/energy.2018.5.658

[6] Benali, M., Hamad, T., Belkhair, A. and Hamad, Y. (2019) Investigating the Use of Combined Hydrogen, Heat and Power System for Omar Al-Mukhtar University Campus. Advances in Biological Chemistry, 9, 31-44. 
https://doi.org/10.4236/abc.2019.91003

[7] Jardine, J., Sundfeld, E. and Durães, F.M. (2013) Availability of Information about Sustainable Bioenergy Technologies: The Agro-Energy Tree of Knowledge. Journal of Sustainable Bioenergy Systems, 3, 260-264.

https://doi.org/10.4236/jsbs.2013.34035 